\title{
Biopharmaceutical Process of Diclofenac Multi- particulate Systems for Chronotherapy of Rheumatoid Arthritis
}

\section{Romatoid Artritin Kronoterapisinde Diklofenak Çok Birimli Sistemlerin Biyofarmasötik Süreci}

\author{
(D) Sowjanya BATTU1, (D) Prasanna Raju YALAVARTHI²*, (D) Subba REDDY GV³, (D) Saradha RADHAKRISHNAN', (D) Ram Mohan Reddy THUMMALURU', \\ (D) Abbulu KONDE'
}

${ }^{1}$ CMR College of Pharmacy, Department of Pharmaceutics, Hyderabad, India

2Sri Padmavathi School of Pharmacy, Division of Pharmaceutics, Tirupati, India

3JNTUA College of Engineering, Department of Chemistry, Pulivendula, India

\begin{abstract}
Objectives: Diclofenac exhibits limited solubility, low bioabsorption and gastric toxicity. The objective of the study was to address the above limitations and to design a multi-particulate formulation for the chronotherapy of RA.

Materials and Methods: Solid dispersions of DC with SSG and GG were prepared. Uniform-sized ( $400 \mu \mathrm{m})$ non-pareil seeds were coated with solid dispersions to produce immediate-release pellets (DMP-1 and DMP-2) and controlled-release pellets (DMP-3 and DMP-4). The resultant controlled-release pellets were further layered with methacrylate polymers to obtain pulsatile-release pellets (DMPP). Solubility, FTIR, DSC, micrometrics, SEM, drug content, drug release, pharmacokinetics, and stability studies were performed for DMPP.

Results: The solubility of DC was improved by 164 -folds due to the presence of hydrophilic carriers in the solid dispersions. No chemical and physical interactions were noticed in FTIR spectra and also in thermograms. A fluidized bed processor facilitated the production of high-quality, circular, and regular pellets with an angle of repose less than 19.5 degrees and DC content between $95.18 \%$ and $98.87 \%$. The maximum drug was released from DMPP at the end of 12 hours. DMP-1 and DMP-2 pellets had $2 \mathrm{hr}$ of drug release and pulsatile, controlled-release pellets had a $6 \mathrm{hr}$ lag phase followed by $12 \mathrm{hr}$ controlled release. Both DMP-1 and DMP-2-immediate showed first-order release followed by Hixson-Crowell kinetics, whereas DMPP pellets followed zero-order release with Higuchi's kinetics. The maximum concentration of DC in plasma was $400.8 \mathrm{ng} / \mathrm{mL}$ at $5 \mathrm{hr}$ for DMP-2 and $381.1 \mathrm{ng} / \mathrm{mL}$ at $14 \mathrm{hr}$ for DMPP-5. The solubility of DC was increased with the application of solid dispersion and in turn increased the pharmacokinetics. The pellets were plausibly stable over a period of 90 days.

Conclusion: Thus, multi-particulate pulsatile systems of DC were as effective as chronotherapeutics in the treatment of circadian rhythm-based ailments such as RA.
\end{abstract}

Key words: Chronomodulation, circadian, fluidized bed, hydrophilic carrier, NSAID, Wurster process

ÖZ

Amaç: Diklofenak sınırlı çözünürlük, düşük biyoabsorpsiyon ve gastrik toksisite gösterir. Çalıșmanın amacı, yukarıdaki kısıtlamaları ele almak ve RA'nın kronoterapisi için çok birimli bir formülasyon tasarlamaktır.

Gereç ve Yöntemler: DC, SSG ve GG ile katı dispersiyonları hazırlandı. Aynı boyutlu ( $400 \mu \mathrm{m})$ nonpareil çekirdekler, hemen salım yapan pelletler (DMP-1 ve DMP-2) ve kontrollü salımlı pelletler (DMP-3 ve DMP-4) üretmek için katı dispersiyonlarla kaplandı. Elde edilen kontrollü salım pelletleri, pulsatil salım pelletleri (DMPP) elde etmek için metakrilat polimerleri ile daha da katmanlı hale getirildi. DMPP için çözünürlük, FTIR, DSC, mikrometrik, SEM, etkin madde içeriği, etkin madde salımı, farmakokinetik ve stabilite çalışmaları yapıldı.

Bulgular: DC'nin çözünürlüğü, katı dispersiyonlardaki hidrofilik taşıyıcıların varlığına bağlı olarak 164 kat arttı. FTIR spektrumunda ve termogramlarda kimyasal ve fiziksel etkileșimler gözlemlenmedi. Akışkanlaştıran yataklı işlemci, 19.5 dereceden daha az bir akış açısı ve \%95.18 ile \%98.87 arasında DC içeriği olan yüksek kaliteli, yuvarlak ve düzenli pelletlerin üretimini kolaylaştırdı. Maksimum etkin madde 12 saat sonunda DMPP'den salındı.

*Correspondence: E-mail: kanishka9002@gmail.com, Phone: +917661976616 ORCID-ID: orcid.org/0000-0001-7859-0475

Received: 05.07.2017, Accepted: 24.08.2017

๑Turk J Pharm Sci, Published by Galenos Publishing House. 
DMP-1 ve DMP-2 pelletleri 2 saatlik pulsatil etkin madde salımına sahipti ve kontrollü salımlı pelletler 6 saat gecikme fazının ardından 12 saat kontrollü salıma sahipti. Hem DMP-1 hem de DMP-2-hemen birinci dereceden salım ve ardından Hixson-Crowell kinetiğini gösterirken, DMPP pelletleri ardından Higuchi kinetikle sıfır derece salım gösterdi. Plazmada maksimum DC konsantrasyonu DMP-2 için 5 saatte $400.8 \mathrm{ng} / \mathrm{mL}$ ve DMPP-5 için 14 saatte $381.1 \mathrm{ng} / \mathrm{mL}$ olmuştur. DC'nin çözünürlüğü katı dispersiyonun uygulanmasıyla arttırılmış ve bunun sonucunda farmakokinetik özellikler artmıştır. Pelletler, 90 günlük bir süre zarfında makul derecede kararlıdır.

Sonuç: Bu nedenle, DC'nin çok birimli pulsatil sistemleri, RA gibi sirkadiyen ritim temelli hastalıkların tedavisinde kronoterapötikler kadar etkiliydi. Anahtar kelimeler: Kronomodülasyon, sirkadiyen, akışkanlaştıran yatak, hidrofilik taşıyıcı, NSAID, Wurster süreci

\section{INTRODUCTION}

Rheumatoid arthritis (RA) is a chronic progressive autoimmune disorder that affects the dense innervation in the joint capsule and synovium, resulting in peripheral inflammation. Chronic inflammation and pain in the fingers, wrists, elbows, shoulders, knees, feet, and ankles occur in RA..$^{-3}$ At a conference in Paris in 2010, "pain modifying analgesic drugs" ${ }^{4}$ were proposed for the management of RA. The clinical treatment options for RA are non-steroidal anti-inflammatory drugs (NSAIDs), opioid analgesics, tricyclic antidepressants, corticosteroids, anticonvulsants, topical agents, and serotonin norepinephrine reuptake inhibitors. ${ }^{5}$ However, each category of drug holds its own limitations. Disease-modifying antirheumatic drugs (DMARDs) are currently recommended for the treatment of arthritis. Triple-therapy with other drugs such as methotrexate, sulfasalazine, and hydroxychloroquine is the flourishing combination with DMARDs. High dosing, long-term use of the above mentioned medications develops gastric mucosal damage, tolerance, and accumulation of drug metabolites in the kidney, liver, and causes nephro- and hepatotoxicity. ${ }^{6}$

NSAIDs are the most commonly prescribed therapeutic agents in the management of RA, as with other causes of pain. Among the notable NSAIDs, diclofenac (DC), a fenamic acid derivative, is usually prescribed due its potentiality against pain and inflammation in patients with RA. DC is believed to inhibit the synthesis of substance $P$, a pro-inflammatory neuropeptide, and nociceptive prostaglandins in synovial tissue as well as in blood, and thus it is useful in the treatment of RA. ${ }^{7}$ DC, an insoluble Biopharmaceutics Classification System (BCS) class II drug, has a $t_{1 / 2}$ of $2 \mathrm{hr}$ and low bioavailability. ${ }^{8}$ Nevertheless, the conventional oral medication of $D C$ results with severe gastric mucosal damage and other adverse effects of NSAIDs. ${ }^{9}$ A dose form that releases drug according to time (circadian rhythm) would be a promising system because the severity of joint pain, surrounding muscle stiffness, and fatigue in patients with RA is related with the circadian rhythm and is mostly observed in the early hours. Nowadays, Pulsatile ${ }^{\circledR}$ and Diffucap ${ }^{\circledR}$ systems are gaining much research interest in the chronotherapy of circadian rhythm-based ailments so as to release the drug after a predetermined lag phase. Multi-particulate formulations are composed of immediate- and controlled-release particulates and are superior because they present diverse drug delivery patterns in a circadian fashion. ${ }^{10,11}$

DC, a regular medication used in the management of RA, was chosen as the model drug in this study. ${ }^{12}$ The aim was to develop multi-particulate systems of DC-containing immediate- and pulsatile-controlled release pellets using non-pareil sugar seeds to avoid gastric mucosal damage and enable pulsatile release in the small intestine.

\section{EXPERIMENTAL}

\section{Materials}

DC and non-pareil seeds were donated by M/s. Lee Pharma, Visakhapatnam, India. Guar gum (GG), sodium starch glycolate (SSG), eudragit RS100 and eudragit L100 were purchased from S.D. Fine Chem., Mumbai, India. All other chemicals and reagents used in the study were of analytical grade.

\section{Preparation of solid dispersions of $D C$}

Solid dispersions of DC were prepared using GG and SSG in 1:1 and 1:2 weight ratios as mentioned in Table 1 . The ingredients were kneaded thoroughly in a glass mortar for about $20 \mathrm{~min}$ until a uniform mass was formed. The resultant mass was screened through \#80 mesh and kept in a vacuum desiccator for further evaluation and formulation of pellets. ${ }^{13}$

\section{Solubility study}

An excess of solid dispersion was taken into calibrated glass vials containing $10 \mathrm{~mL}$ of $0.1 \mathrm{~N} \mathrm{HCl}, \mathrm{pH} 6.8$ and 7.4 phosphate buffer solutions. The resultant solutions were equilibrated at $37^{\circ} \mathrm{C}$ for $72 \mathrm{hr}$ using a rotary shaker. After equilibration, the solutions were filtered through a $0.45-\mu m$ nylon filter and assayed using an ultraviolet (UV)-visible spectrophotometer (Analytical Technologies, T 70) at $276 \mathrm{~nm}^{14}$

\section{Step 1: Preparation of multi-particulate pellets}

A known quantity (a batch) of non-pareil seeds were coated with DC:SSG and DC: GG solid dispersions in 1:1 and 1:2 proportions. This results in the production of immediate- and controlled-release pellets.

Non-pareil seeds coating with solid dispersion using the solution-layering technique

About 150 g of non-pareil seeds (sugar spheres) were transferred into the vertical chamber of a fluidized bed processor (GPCG 1.1. Glatt, D-Binzen) (Wurster process). A solution-layering process was initiated with an inlet temperature of $45-50^{\circ} \mathrm{C}$ by layering the solid dispersions (300 g) of step 1, on pellets using spray guns, atomized at 2-4.5 bar, and operated at a 60-120 g/min spray rate until the bed was wet and tacky. The process was continued for $45 \mathrm{~min}$ to produce the desired size of immediate-

$\begin{aligned} & \text { Table 1. Composition of diclofenac immediate- and controlled- } \\
& \text { release pellets }\end{aligned}$
\begin{tabular}{lllll} 
Solid dispersion composition & DMP-1 & DMP-2 & DMP-3 & DMP-4 \\
\hline DC:SSG & $1: 1$ & $1: 2$ & - & - \\
\hline DC:GG & - & - & $1: 1$ & $1: 2$ \\
\hline
\end{tabular}

DC: Diclofenac, SSG: Sodium starch glycolate, GG: Guar gum 
release pellets (DMP-1 and DMP-2) and controlled-release pellets (DMP-3 and DMP-4). The pellets obtained were sifted through \#14 and \#18 sieves and the controlled-release pellets retained over \#18 were selected for step $2 .{ }^{15}$

Step 2: Preparation of pulsatile controlled-release pellets

In this step, DMP-3 and DMP-4 pellets (controlled-release pellets) were coated with solutions of eudragit RS100 and eudragit L100 prepared in the solvent mixture of triethylamine (plasticizer) and isopropyl alcohol. The eudragit compositions of are presented in Table 2. The process parameters employed in this step were similar to that of step 1. Step 2 resulted in the formation of pulsatile-release pellets (DMPP-1 to DMPP5). Pulsatile pellets sifted and retained over \#20 mesh were selected for further characterization and evaluation studies. ${ }^{16,17}$

Attenuated total resonance-Fourier-transform infrared (ATRFTIR) spectroscopy

The chemical compatibility of DC and polymer mixtures was examined using an ATR-FTIR spectrometer (Agilent CARY 630 ATR-FTIR). The sample to be tested was placed on a diamond ATR crystal and analyzed by means of Agilent resolutions pro software. Each spectrum was checked with 32 single average scans at $4 \mathrm{~cm}^{-1}$ resolution in the $400-4000 \mathrm{~cm}^{-1}$ absorption region.

\section{Differential scanning calorimetry (DSC)}

Thermal analysis of DC and polymer mixtures was performed using a DSC (Shimadzu DSC-50) to check the physical compatibility. During each scan, about 1 to $2 \mathrm{mg}$ of the sample was positioned in sealed aluminum sample pans at a rate of $10^{\circ} \mathrm{C} /$ min under a nitrogen atmosphere between $25^{\circ} \mathrm{C}$ and $350^{\circ} \mathrm{C}$. An empty aluminum pan was used as reference.

\section{Scanning electron microscopy (SEM)}

The surface morphology and cross-section of the prepared pellets was determined using a SEM (Jeol, JSM-1600, Tokyo, Japan). The pellets were coated with fine gold in a $10 \mathrm{~mA}$ ion current for 5 min under 0.1 Torr pressure using an ion sputter and laden on studs for examination.

\section{Drug content}

A batch of pellets was transferred into a calibrated volumetric flask and dissolved in $10 \mathrm{~mL}$ of methanol by ultra-sonication for $10 \mathrm{sec}$. The volume of the preparation was made up to $100 \mathrm{~mL}$ with the same, filtered, and assayed.

Table 2. Composition of diclofenac pulsatile pellets

\begin{tabular}{lll}
\multirow{2}{*}{ Formulation } & \multicolumn{2}{l}{ Coating composition (\%) } \\
\cline { 2 - 3 } & Eudragit L100 & Eudragit RS100 \\
\hline DMPP-1 & 100 & - \\
\hline DMPP-2 & - & 100 \\
\hline DMPP-3 & 50 & 50 \\
\hline DMPP-4 & 60 & 40 \\
\hline DMPP-5 & 40 & 60 \\
\hline
\end{tabular}

\section{Entrapment efficiency and drug loading}

A batch of pellets (DMP-1 to 4 and DMPP-1 to 5) equivalent to $100 \mathrm{mg}$ of DC were transferred into a standard Vensil ${ }^{\circledR}$ flask containing $100 \mathrm{~mL}$ of phosphate buffer $(\mathrm{pH}$ 6.8) and stored overnight. The sample solution was filtered through a 0.44$\mu \mathrm{m}$ nylon filter to remove undissolved portions of pellets and analyzed at $276 \mathrm{~nm}$. Average of three estimations was considered for each batch of pellets formulated in the study. The entrapment efficiency and drug loading of pellets were calculated from equations (1) and (2):18,19

$\%$ Entrapment efficiency $=\frac{\text { Actual drug loading }}{\text { Theoretical drug loading }} \times 100$

$\%$ Drug loading $=\frac{\text { Mass of drug in pellets }}{\text { Mass of pellets }} \times 100$

\section{In vitro dissolution study}

Pellets of DMP- 1 to DMP-4 and DMPP-1 to DMPP- 5 equivalent to $100 \mathrm{mg}$ of drug were subjected to in vitro drug release studies using USP type I dissolution test apparatus at $37^{\circ} \mathrm{C}$ and $50 \mathrm{rpm}$ in $0.1 \mathrm{~N} \mathrm{HCl}, \mathrm{pH} 6.8$ and $\mathrm{pH} 7.4$ as dissolution media for the first $2 \mathrm{hr}$, the next $3 \mathrm{hr}$, followed by the next $13 \mathrm{hr}$, respectively. Fivemilliliter aliquots were withdrawn at various time intervals by maintaining sink conditions, filtered, and analyzed. The study was repeated for six independent observations and the results were built into diverse kinetic models.

\section{In vivo study}

Male rabbits aged 10-14 weeks weighing 2-3 kg were chosen for the study. The animals were housed under 12-12-hr light-dark cycles and fed with standard diet and water. The study process was approved by the Institutional Animal Ethics Committee (CPCSEA/1657/IAEC/CMRCP/PhD-15/43). Twelve rabbits were divided into three equal groups (group 1, group 2, and group 3 ) and were depilated on the dorsal surface of the ear pinna. Animals were fasted for $24 \mathrm{hr}$ before the study. The dose of the drug to be administered was calculated based on the rabbit's body weight using the formula:

Rabbit dose $=\frac{\text { Total Dose (in humans) } X 0.07 \text { (for } 1.5 \mathrm{~kg} \text { rabbit) }}{1.5}$ 1.5

Groups 1, 2, and 3 were administered DC, DMP2, and DMPP5 samples, respectively. Blood samples of about $1 \mathrm{~mL}$ were collected into heparinized Eppendorf tubes at regular time intervals. The samples were shaken thoroughly, centrifuged at $1500 \mathrm{rpm}$, and plasma was collected. A previously developed and validated high-performance liquid chromatography (HPLC) method was employed ${ }^{20}$ to determine the plasma drug concentrations as a function of time. The $\mathrm{C} 18(250 \mathrm{~mm} \times 4.6$ $\mathrm{mm}, 5 \mu \mathrm{m}$ ) column, a mixture of acetonitrile and methanol $(70: 30, v / v)$ as the mobile phase, and UV detector $(276 \mathrm{~nm})$ were adopted and Empower software version-2 was used to assay the $D C$ concentrations in plasma against $D C$ as an internal standard. Samples of about $20 \mu \mathrm{L}$ were injected into the HPLC 
system (Waters, 2695) after filtering the plasma through a 0.2 $\mu \mathrm{m}$ membrane filter.

\section{Statistical Analysis}

The mean concentrations of DC in plasma samples as a function of time were calculated. The pharmacokinetic parameters such as $t_{1 / 2}, K_{e}$ and $V_{d}$ were characterized and compared statistically using analysis of variance (ANOVA) and the Tukey-Krammer test was applied for the columns comparison. $P<0.05$ was considered a statistically significant correlation.

\section{Stability study}

Accelerated stability testing of pellets was conducted at $25 \pm 2^{\circ} \mathrm{C} / 60 \pm 5 \%$ relative humidity $(\mathrm{RH})$ and $40 \pm 2^{\circ} \mathrm{C} / 75 \pm 5 \% \mathrm{RH}$ conditions as per the International Council for Harmonisation of Technical Requirements for Registration of Pharmaceuticals for Human Use guidelines for a period of 120 days. The pellets were then tested for their flow properties, drug content, and in vitro drug release. ${ }^{21,22}$

\section{RESULTS}

Pulsatile drug delivery as multi-particulate systems have been demonstrated to be successful technologies to overcome limitations such as low solubility and less bioabsorption faced by BCS class II and IV drugs as single-unit drug delivery systems. This solubility study resulted with increased solubility of DC by 164-fold because solid dispersion was employed along with hydrophilic polymers. The resultant amorphous solid dispersions of DC displayed good micrometrics.

The FTIR spectra (Figure 1) of DC confirmed the existence of peaks at $3317,1677,1120$, and $745 \mathrm{~cm}^{-1}$ due to $\mathrm{NH}$ stretching, $\mathrm{C}=\mathrm{O}$ stretching, $\mathrm{C}-\mathrm{O}$ bending, and $\mathrm{C}-\mathrm{Cl}$ bending as characteristic functional groups of DC. Similar functional groups indicating peaks were observed without significant shifting of DC in the DMPP-5 mixture. As shown in Figure 2, DSC thermograms displayed endothermic peaks of DC at $276^{\circ} \mathrm{C}$ and DMPP-5 at $275^{\circ} \mathrm{C}$, respectively.

The SEM image (Figure 3) of pellets demonstrated smooth, well separated, spherical, and uniformly-distributed, micron-sized

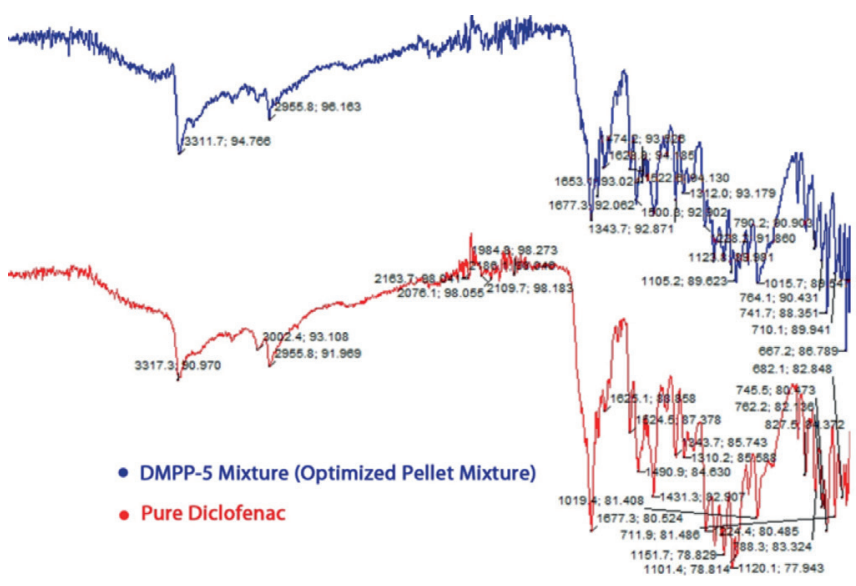

Figure 1. Fourier-transform infrared spectra of diclofenac and DMPP-5 pellet mixture particles with 400-500 $\mu \mathrm{m}$ range. The pellets (both types), prepared using the Wurster process, displayed substantial entrapment efficiencies and drug-loading capabilities as mentioned in Table 3.

In vitro drug release profiles of the DC pellets are depicted in Figure 4 and 5. SSG, a hydrophilic carrier composed DMP-1 and DMP-2 pellets, demonstrated burst drug release as $94.2 \%$ and $99.5 \%$ at the end of the second hour. The controlled-release pellets, DMP-3 and BMP-4, had $98.9 \%$ and $99.1 \%$ at end of the tenth hour due to the composition of hydrocolloidal polymer GG. The pulsatile-release pellets, DMPP-1-DMPP-5, showed

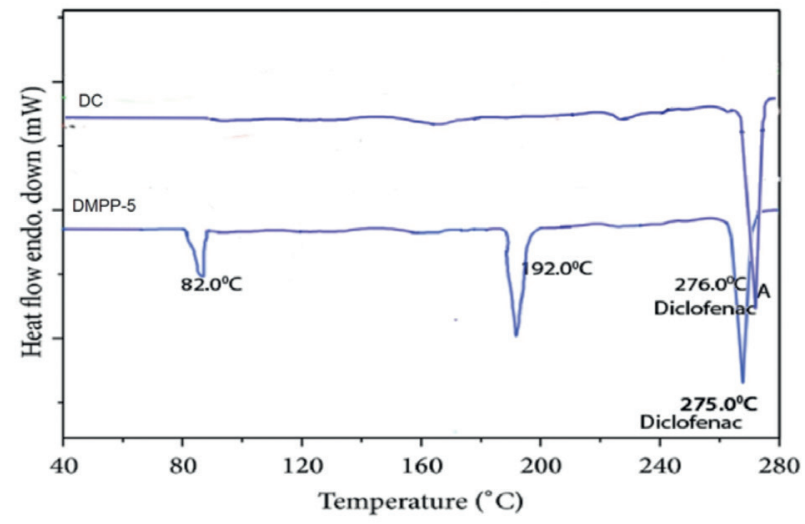

Figure 2. Thermograms of diclofenac and DMPP-5 pellet mixture DC: Diclofenac

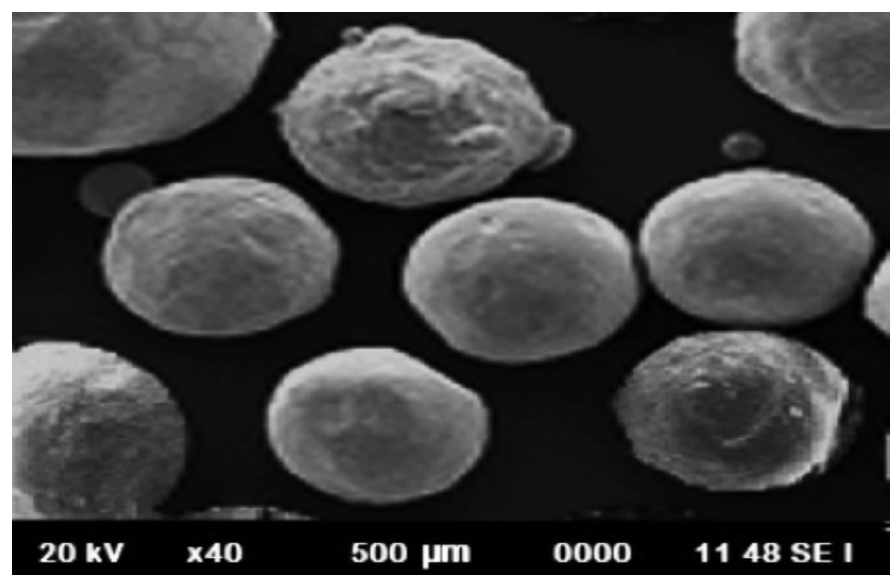

Figure 3. Scanning electron microscopy image of DMPP-5 pellets

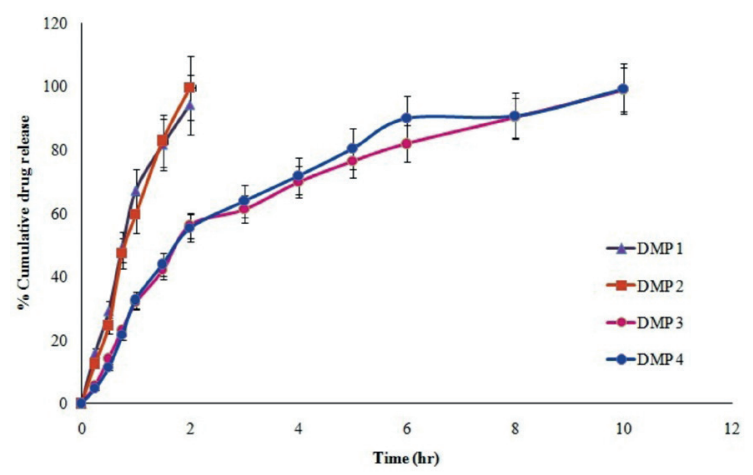

Figure 4. Percent drug release of DMP-1 to DMP-4 pellets 
$96.1 \%, 96.3 \%, 97.4 \%, 99.1 \%$, and $99.5 \%$, respectively, at the end of the $18^{\text {th }}$ hour (with a 6-hr lag phase). The release of DC from immediate-release pellets followed first-order release with Hixson-Crowell cube root model kinetics, whereas pulsatilerelease pellets followed zero-order with the Higuchi kinetic model.

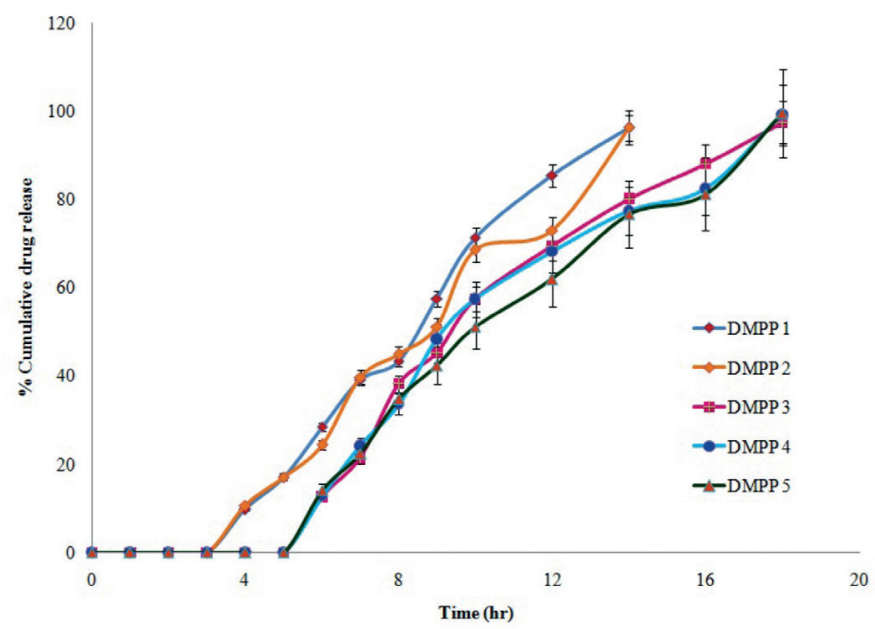

Figure 5. Percent drug release from pulsatile-release pellets (DMPP-1 to DMPP-5)

\section{Table 3. Entrapment efficiency and drug loading properties}

\begin{tabular}{lll} 
Formulation & Entrapment efficiency (\%) & Drug loading (\%) \\
\hline DMP-1 & $96.0 \pm 0.10$ & $68.0 \pm 0.10$ \\
\hline DMP-2 & $98.3 \pm 0.09$ & $70.0 \pm 0.14$ \\
\hline DMP-3 & $97.9 \pm 0.20$ & $69.9 \pm 0.11$ \\
\hline DMP-4 & $98.2 \pm 0.15$ & $70.1 \pm 0.12$ \\
\hline DMPP-1 & $97.6 \pm 0.12$ & $69.7 \pm 0.21$ \\
\hline DMPP-2 & $97.4 \pm 0.30$ & $69.5 \pm 0.15$ \\
\hline DMPP-3 & $97.5 \pm 0.13$ & $69.6 \pm 0.12$ \\
\hline DMPP-4 & $97.6 \pm 0.09$ & $69.7 \pm 0.23$ \\
\hline DMPP-5 & $98.9 \pm 0.11$ & $70.6 \pm 0.16$ \\
\hline
\end{tabular}

Values are expressed as mean $\pm S D, n=3$
The developed HPLC method eluted the DC peak with a retention time of $2.34 \mathrm{~min}$ as shown in Figure 6 . The limit of detection and limit of quantification for the HPLC method was found to be 3 and $9 \mathrm{ng} / \mathrm{mL}$, respectively. Upon assaying the plasma samples using this validated HPLC method, the plasma kinetics as function of time were demonstrated in Figure 7. The pharmacokinetics of the DMP-2 pellets such as $t_{1 / 2}, K_{e}$ and $V_{d}$ were found to be increased by 2.03, 1.733, and 1.55fold, respectively. Bioavailability parameters viz., $C_{\max } t_{\max }$ and AUC were increased by 1.9, 1.72, and 1.25 times, respectively, when compared with DC. In the case of pulsatile pellets, the DMPP-5 formulation had 5.78, 4.1, and 1.82-fold increase in

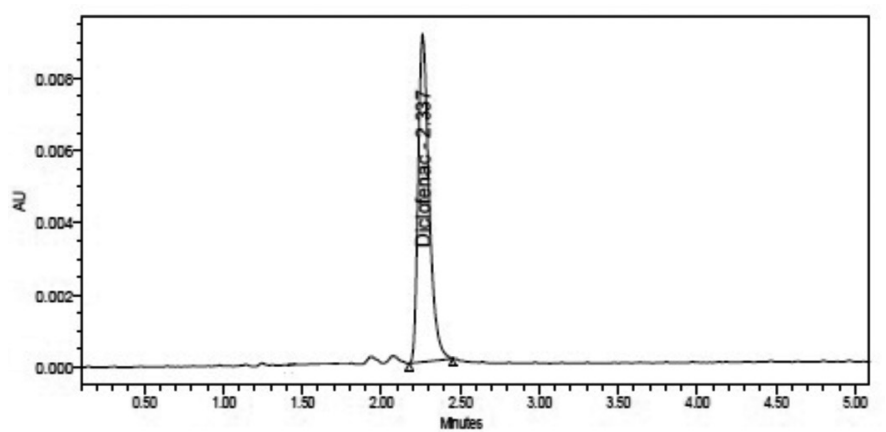

Figure 6. Chromatogram of diclofenac

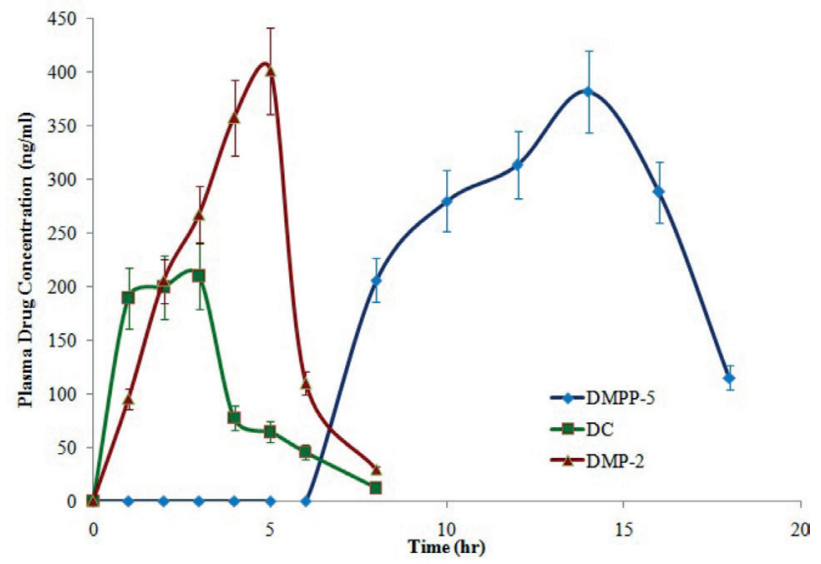

Figure 7. Plasma drug concentration-time profile DC: Diclofenac

Table 4. In vivo pharmacokinetic parameters (mean \pm SEM)

\begin{tabular}{|c|c|c|c|c|}
\hline Pharmacokinetic parameters & $\mathrm{DC}$ & DMP-2 & DMPP-5 & Test of significance \\
\hline$C_{\max }(\mathrm{ng} / \mathrm{mL})$ & $209.8 \pm 106.5$ & $400.8 \pm 125$ & $381.1 \pm 106$ & $\mathrm{~S}$ \\
\hline $\mathrm{T}_{\max }(\mathrm{hr})$ & $2.9 \pm 2.2$ & $5.0 \pm 2.9$ & $14.0 \pm 3.1$ & $\mathrm{~S}$ \\
\hline$t_{1 / 2}(h r)$ & $2.0 \pm 1.9$ & $4.06 \pm 1.1$ & $11.56 \pm 2.9$ & S \\
\hline $\mathrm{K}_{\mathrm{el}}\left(\mathrm{hr} \mathrm{r}^{-1}\right)$ & $0.983 \pm 0.017$ & $1.7042 \pm 0.069$ & $4.0306 \pm 1.54$ & $\mathrm{~S}$ \\
\hline $\mathrm{AUC}_{0-8}\left(\mathrm{ng} / \mathrm{hr} / \mathrm{mL}^{-1}\right)$ & $1724 \pm 123.8$ & $2165 \pm 169.9$ & - & S \\
\hline $\mathrm{AUC}_{0-18}\left(\mathrm{ng} / \mathrm{hr} / \mathrm{mL}^{-1}\right)$ & $2973 \pm 138.2$ & - & $3897 \pm 111.5$ & $\mathrm{~S}$ \\
\hline
\end{tabular}

S: Significant, SEM: Scanning electron microscopy, DC: Diclofenac 
pharmacokinetics and about a 1.82, 4.82, and 1.31-times increase in bioavailability parameters, respectively, as given in Table 4.

The physicochemical properties for all pellets were intact over a period of 90 days due to the eudragit coatings. There were no changes in the evaluation parameters of the pellets even after exposure to various temperature and $\mathrm{RH}$ conditions.

\section{DISCUSSION}

The kneading technique employed in the formulation facilitated the entanglement of particles to the molecular level as polymeric networks and therefore enhanced solubility of DC was achieved with solid dispersions. Moreover, the solid dispersions of DC showed amorphous geometry with excellent micrometric properties.

SSG and GG have become well established as carriers in the recent past and were shown to be compatible with $D C$ moiety as evidenced in the FTIR spectra. There were no chemical bonds established between DC and carriers other than hydrogen bonding, which was evidenced in the wave numbers of the FTIR spectrum. Thus, the spectra showed no chemical interactions between DC and the carriers selected in the study. The same was attributed in thermograms of DMPP pellets because a minor shift in the endothermic peak of DC was identified in DMPP-5's thermogram as a characteristic interaction between drug and the selected carriers.

The defined surface morphology of the pellets was possible only due to the accurate layering of DC on sugar spheres. The dimensions of pellets were linearly increased with the composition of eudragit as coating solutions and the same result was seen in SEM images. Pulsatile pellets were relatively larger than immediate-release pellets because they had undergone two steps of coating and also had a methacrylate polymer coating. The Wurster process using fluidization was successful in producing the non-agglomerated, free-flowing and moderately high DC content (95.18-98.87\%) pellets. The pellets with good entrapment efficiency and drug loading were selected for coating with eudragits so as to produce pulsatalie drug release pellets.

Eudragit RS100, a polymer of enteric grade and a cationic polymer with low permeability, provides additional sustaining activity of drug release along with the gelling properties of GG. Eudragit L100, which is an anionic polymer with high permeability, helps in maintaining the lag phase for about 6 hr. DMPP pellets were composed of a swellable polymer, GG, and enteric polymers (Eudragit L100 and Eudragit RS100). Optimized pulsatile release of DC was achieved with desired lag phase from DMPP pellets owing to typical composition of hydrocolloidal GG and pH dependent eudragits.

Enhanced oral absorption of DC was resulted with multiparticulates. Quick onset of action from DMP-2 formulation was displayed due to presence of SSG, a hydrophilic carrier and same was evidenced in the HPLC data of plasma DC concentrations. Micron-size pellets of immediate-release contributed to the loading dose, and the pulsatile pellets contributed to the maintenance dose of drug in rabbits. The contribution of GG, a polycolloidal polymer, resulted with controlled release of DC from DMPP to reach a maximum concentration in plasma. The desired lag phase of $6 \mathrm{hr}$ was achieved with a typical composition of anionic and cationic methacrylate polymers (Eudragits) at 40:60 ratios. Increased bioabsorption and pharmacokinetics of DC by multi-particulate pulsatile formulation were evident and hence it was attributed to reach adequate concentrations of DC at the synovium to reduce the inflammation. Administration of DMP-2 and DMPP-5 pellets as multi-particulate formulations of DC could produce both immediate- and controlled-release profiles of DC at a predetermined time in the small intestine so as to cater for the requirements of chronotherapy of RA. The physical stability of the pellets was due to the application of superior technology (fluidized coating) and methods (solution layering) in the study.

\section{CONCLUSIONS}

Solid dispersions were prepared using different hydrophilic polysaccharides and methacrylate polymers to address the solubility issues of DC. A novel solution layering technique was employed in association with a fluidized bed processor to obtain typically micron-sized, smooth-surfaced and spheronized pellets of the immediate-release and controlled-release category. Further, controlled-release pellets were coated with enteric polymers to produce a 6-hr lag phase in drug release. Promised in vitro drug release profiles were achieved by pulsatile technology-based multi-particulates of DC to cater for the needs of chronotherapy of circadian rhythmbased chronic diseases such as RA. Thus, the suitability of applied technologies in the design of multi-particulate drug delivery systems in chronotherapy of RA using DC was convincingly proved using in vitro evaluations. The outcomes of the in vitro study were further fortified by in vivo studies using rabbits. While characterizing the plasma drug concentrations using sensitive and precise HPLC methodology, plasmadrug parameters such as $t_{1 / 2}$, and $K_{e}$ were proved as suitable chronopharmacokinetic parameters. The characteristics and parameters of bioavailability also contributed to this chronomodulated delivery of DC. It was concluded that, the design of spheronized pulsatile pellets of DC is useful in the chronotherapy of RA, but scale-up techniques are required for commercial viability.

\section{ACKNOWLEDGEMENTS}

The authors are thankful to M/s. Lee Pharma, Visakhapatnam for gratis of DC.

Conflict of Interest: No conflict of interest was declared by the authors.

Financial Disclosure: The research received no specific grant from any funding agency in public, commercial or not-for-profit sectors.

\section{REFERENCES}

1. Cheng HY, Penninger JM. DREAMing about arthritic pain. Ann Rheum Dis. 2004:63(Suppl 2):72-75. 
2. Huskisson EC, Hart FD. Pain threshold and arthritis. Br Med J. 1972;4:193195.

3. Konttinen YT, Honkanen VE, Grönblad M, Keinonen M, Santavirta N, Santavirta S. The relation of extraarticular tenderness to inflammatory joint disease and personality in patients with rheumatoid arthritis. $J$ Rheumatol. 1992;19:851-855.

4. Castillo BA, EI Sallab RA, Scott JT. Physical activity, cystic erosions, and osteoporosis in rheumatoid arthritis. Ann Rheum Dis. 1965;24:522-527.

5. Van Laar M, Pergolizzi JV Jr, Mellinghoff HU, Merchante IM, Nalamachu S, O'Brien J, Perrot S, Raffa RB. Pain treatment in arthritis-related pain: beyond NSAIDs. Open Rheumatol J. 2012;6:320-330.

6. Perrot S. Should we switch from analgesics to the concept of "painmodifying analgesic drugs (PMADS)" in osteoarthritis and rheumatic chronic pain conditions. Pain. 2009;146:229-230.

7. Peesa JP, Yalavarthi PR, Rasheed A, Mandava VBR. A perspective review on role of novel NSAID prodrugs in the management of acute inflammation. J Acu Dis. 2016;5:364-381.

8. Sweetman SC. Martindale: The complete drug reference, Royal Pharmaceutical Society, (36th ed). London; 2009:44.

9. Nandakishore R, Yalavarthi PR, Kiran YR, Rajapranathi M. Selective cyclooxygenase inhibitors: current status. Curr Drug Discov Technol. 2014;11:127-132.

10. Sharma PR, Lewis SA. Design and in vitro/in vivo evaluation of extended release matrix tablets of nateglinide. J Young Pharm. 2013;5:167-172.

11. Vadlamudi HC, Raju YP, Asuntha G, Nair R, Murthy KV, Vulava J. Assessment of hupu gum for its carrier property in the design and evaluation of solid mixtures of poorly water soluble drug - rofecoxib. Curr Drug Deliv. 2014;11:62-71.

12. Kroenke K, Krebs EE, Blair MJ. Pharmacotherapy of chronic pain: a synthesis of recommendations from systematic reviews. Gen Hos Psych. 2009;31:206-219.
13. Prasannaraju Y, Chowdary VH, Jayasri V, Asuntha G, Kumar NK, Murthy KV, Nair R. Bioavailability and pharmacokinetic studies of rofecoxib solid dispersion. Curr Drug Deliv. 2013;10:701-705.

14. Ahuja N, Katare OP, Singh B. Studies on dissolution enhancement and mathematical modeling of drug release of poorly water-soluble carriers. Eur J Pharm Biopharm. 2007;65:26-38.

15. Politis SN, Rekkas DM. Pelletization processes for pharmaceutical applications: a patent review. Recent Pat Drug Deliv Formul. 2011;5:6178.

16. Gowda DV, Aravindram AS, Venkatesh MP, Khan MS. Development and evaluation of clozapin pellets for controlled release. Int J Res Ayur Pharm. 2012;3:611-618.

17. Raval MK, Ramani RV, Sheth NR. Formulation and evaluation of sustained release enteric-coated pellets of budesonide for intestinal delivery. Int J Pharm Investig. 2013;3:203-211.

18. Bhattacharya SS, Banerjee S, Ghosh AK, Chattopadhyay P, Verma A, Ghosh A. A RP-HPLC method for quantification of diclofenac sodium released from biological macromolecules. Int $J$ Biol Macromol. 2013:58:354-359.

19. Nagpal M, Maheshwari D, Rakha P, Dureja H, Goyal S, Dhingra G. Formulation, development and evaluation of alginate microspheres of Ibuprofen. J Young Pharm. 2012;4:13-16.

20. Lu Y, Sturek M, Park K. Microparticles produced by the hydrogel template method for sustained drug delivery. Int J Pharm. 2014:461:258-269.

21. Nanda Kishore R, Yalavarthi PR, Vadlamudi HC, Vandana KR, Rasheed A, Sushma M. Solid self microemulsification of Atorvastatin using hydrophilic carriers: a design. Drug Dev Ind Pharm. 2015;41:1213-1222.

22. Vadlamudi HC, Yalavarthi PR, Mandava Venkata BRM, Thanniru J, Vandana KR, Sundaresan CR. Potential of microemulsified entacapone drug delivery systems in the management of acute Parkinson's disease. J Acu Dis. 2016;5:315-325. 